\title{
CONTROLLED HYPOTENSION DURING OPERATION FOR COARCTATION OF THE AORTA
}

\author{
BY \\ OLE SECHER, ERIK HUSFELDT, AND FREDERIK THERKELSEN \\ From the Departments of Anaesthesia, Surgery $D$, and Surgery $R$, Rigshospitalet, University Clinic \\ of Copenhagen
}

(RECEIVED FOR PUBLICATION OCTOBER 1,1955 )

Since 194861 patients have been operated on for coarctation of the aorta at the University Hospital, Copenhagen. The technical problems of this operation are largely due to the high blood pressure proximal to the stenosis and in the highly developed and dilated collaterals which are forced to act as a by-pass round the stenosis. These dilated and fragile vessels, particularly the intercostal arteries, may bleed profusely, making it difficult to obtain haemostasis. Moreover, since the blood pressure often increases in the course of the operation a considerable amount of blood may be lost.

In a high proportion of the cases the obstruction to flow at the narrowing is almost complete. For this reason there is seldom any material increase in blood pressure when the stenosed part of the aorta is clamped off, unless the subclavian artery has to be clamped too. On the other hand, the blood pressure usually falls quite precipitously when the anastomosis is completed and the flow through the aorta re-established. In order to compensate for this fall, a large volume of blood has to be administered in the course of a short time. In some cases, intra-arterial transfusion may be required. In an endeavour to avoid this sudden fall in pressure, the forceps clamping off the aorta should be released gradually once the anastomosis is completed. This is illustrated by the blood pressure curve in Fig. 1.

The introduction of controlled hypotension by ganglion-blocking agents (Davison, 1950 ; Enderby, 1950) offers considerable advantages in surgery generally, and in fact the immediate advantages of controlled hypotension in these operations are great. Haemostasis is facilitated, haemorrhage is reduced, and the otherwise inevitable increase in blood pressure when the collateral circulation is ligatured is avoided. Moreover, there is practically no further fall in blood pressure when the clamps are removed from the aorta. The time required for the operation is materially cut down. Owing to the slight haemorrhage, less blood has to be administered, and the rapid transfusions required because of the major decrease in blood pressure are avoided.

Controlled hypotension during surgery for the relief of the aorta has been advocated by Lucas (1954), Griffith (1954), and Lundskog (1954), but they have not yet published their actual results.

During controlled hypotension particular attention has to be paid to haemostasis, since negligible oozing may be transformed into brisk haemorrhage when the blood pressure rises again.

Eighteen patients have been operated on using this technique in Rigshospitalet, 17 with resection of the stenosed area. In the remaining instance, the intervention was exploratory. In the major group one patient died shortly after the operation (see later), and another died after re-operation due to thrombosis.

\section{TEChNiQue}

In 12 instances anaesthesia was induced with an intravenous barbiturate and in six with $\mathrm{N}_{2} \mathrm{O}$ or cyclopropane. In 15 cases it was maintained by relaxant drugs and $\mathrm{N}_{2} \mathrm{O}$, and in the remaining three cases with cyclopropane alone or $\mathrm{N}_{2} \mathrm{O}$ and cyclopropane.

The ganglion-blocking drug "pendiomid" (Ciba), which is relatively short-acting, was given intravenously to lower the blood pressure. The initial dose of 50 to $75 \mathrm{mg}$. is given immediately after the patient is placed in the lateral position. This ensures that the blood pressure falls before the incision of the highly vascular muscles. Nevertheless some bleeding is inevitable because of the well-developed vessels in this area.

In Case 8 ( 5 years of age) and Case 9 (10 months), the initial dose was $20 \mathrm{mg}$. and in Case 14 (4 years) $25 \mathrm{mg}$. As the series comprises mainly children and adolescents (there were only two adults, aged 37 and 39), it was somewhat difficult to achieve the desired degree of hypoten- 
Girl. 13 years.

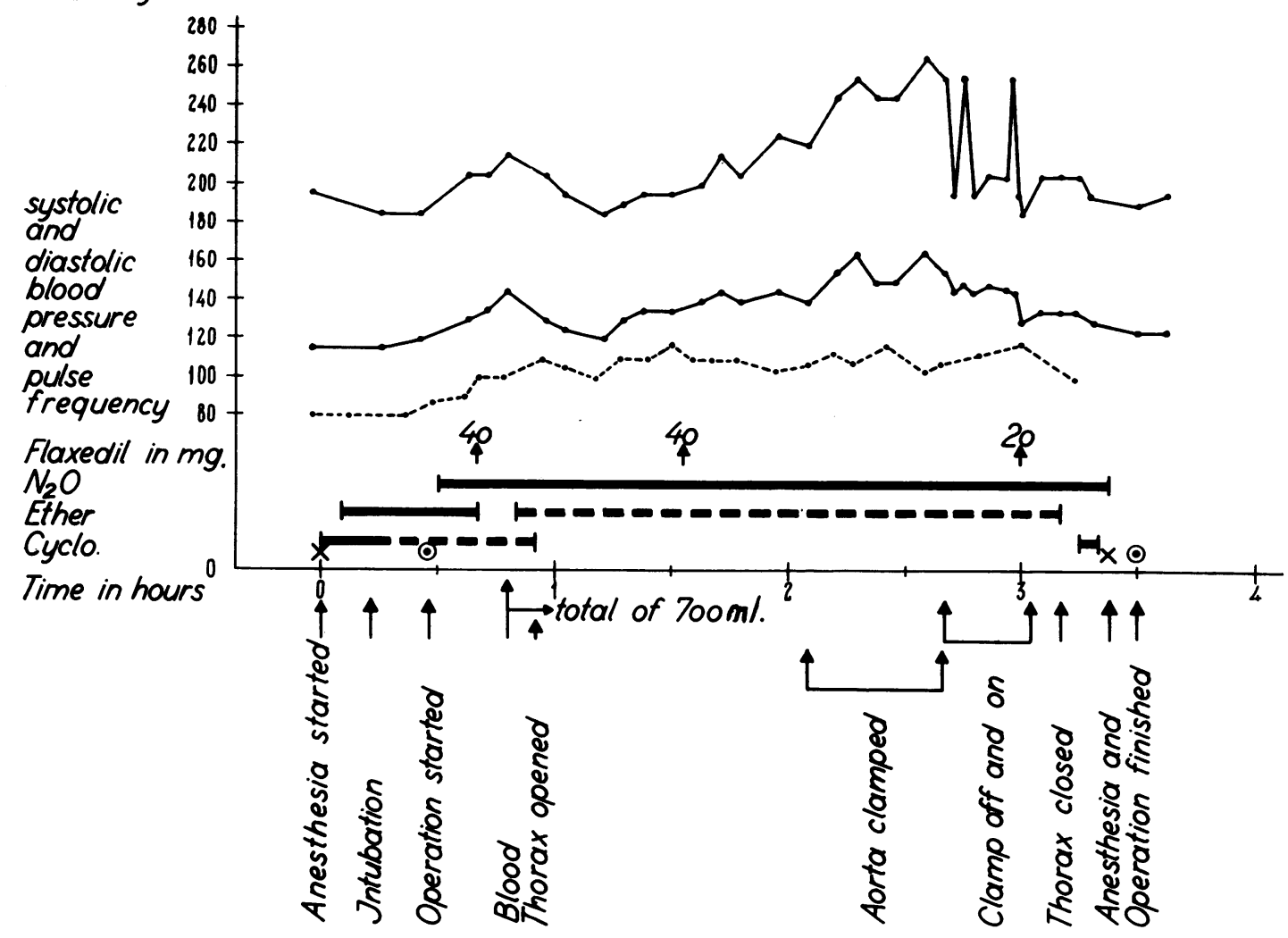

Fig. 1.-Blood pressure and pulse curve from a patient who did not have hypotension.

sion, since this is more difficult in children than in older patients. In most instances the lowest blood pressure reached about $80-90 \mathrm{~mm}$. of mercury and this was obtained only by using a $5-10^{\circ}$ antiTrendelenburg position. Most of the remaining cases were satisfactory in that an increase in blood pressure during operation was avoided. The average blood pressure was about $100-120 \mathrm{~mm}$. $\mathrm{Hg}$ systolic, a lower pressure being registered only during short periods.

As soon as there was a tendency for the pressure to rise, the patients were given supplementary doses of " pendiomid," usually $20-25 \mathrm{mg}$. at a time, the youngest patients $5-10 \mathrm{mg}$., and the oldest $50 \mathrm{mg}$. The range of the number of injections was four to 17 .

All the patients received blood transfusions during the operations, but only very small amounts, merely to compensate for blood loss and not sufficient to counteract the effect of the ganglionblocking agent.
After the anastomosis had been established, no further "pendiomid" was administered, and the blood transfusion was increased with the object of raising the blood pressure to about $120 \mathrm{~mm}$. of mercury. Only one patient (Case 8) required a sympathicomimetic drug to attain this value.

The procedure is illustrated in Fig. 2, which shows the blood pressure curve in Case 6. The entire series is listed in the Table.

\section{COMMENTs}

During induction of anaesthesia, viz., before hypotension was induced and while intubation was being performed, a considerable increase in blood $\stackrel{\oplus}{\rightarrow}$ pressure occurred in four cases owing to a brief period of $\mathrm{CO}_{2}$ accumulation and possibly slight anoxia. In one instance, the blood pressure increased to more than $300 \mathrm{~mm}$. of mercury.

Post-operative vomiting occurred in only one case (No. 1). This patient had a short episode of 
Boy. 15 years.

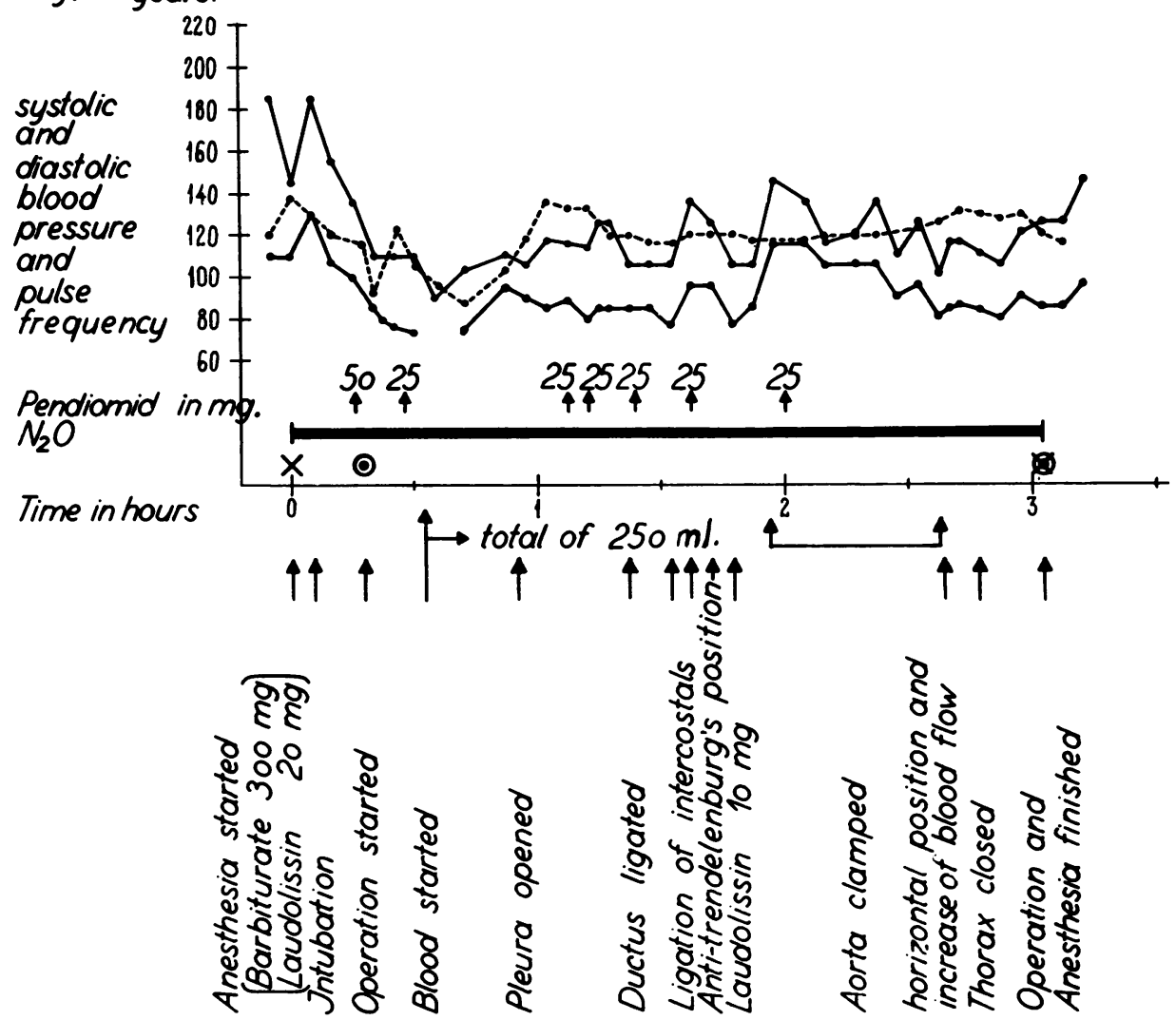

FIG. 2.-Blood pressure and pulse curve from a patient who had controlled hypotension.

decreased blood pressure and cyanosis which rapidly yielded to oxygen.

Another patient (Case 8) had cardiac arrest when the clamps were taken off the aorta. Cardiac massage was started immediately and $5 \mathrm{ml}$. of procaine $1 \%$ and then $0.1 \mathrm{mg}$. of epinephrine were injected into the heart. After seven minutes the heart was beating normally. In addition to the coarctation, this patient had a ventricular septal defect. Postoperatively, he developed pulmonary atelectasis on the operated (left) side. The atelectasis cleared after bronchoscopic aspiration, and the patient recovered without further complications.

Case 11 died shortly after the operation, a patient with a moderate degree of aortic stenosis. Before operation the blood pressure in the upper limbs was about $160 / 90-110 / 85 \mathrm{~mm}$. of mercury, and in the lower limbs $100 / 70 \mathrm{~mm}$. of mercury. When the aorta was clamped off, the blood pressure rose from $65 / 50$ to $125 / 80$, confirmation of the fact that previously there had been a reasonably good flow through the narrowed segment. When the clamps were released the blood pressure fell from $145 / 100$ to $95 / 65$. Towards the end of the operation the pressure was $120 / 90$ and remained around this level for about one hour, when the patient suddenly died after return to the ward. Immediately after the operation the patient was more sleepy than usual, and her reaction to pain less brisk. Necropsy threw no light on the cause of death. Transport to the ward may have been a contributory factor: patients with controlled hypotension are extremely sensitive to any sudden alteration of posture. As we had no recovery room, the patient had to be transported for quite a distance, the journey including mounting a few steps, possibly too soon after operation.

Change of posture may explain too the extreme fall in blood pressure, and the malaise in Case 1 when vomiting occurred immediately after the operation. 
TABLE

\begin{tabular}{|c|c|c|c|c|c|c|c|c|c|c|c|c|}
\hline \multirow{3}{*}{$\begin{array}{l}\text { No. } \\
-\frac{1}{1}\end{array}$} & \multirow{3}{*}{$\begin{array}{l}\begin{array}{c}\text { Age } \\
\text { and } \\
\text { Sex }\end{array} \\
9 \sigma^{*}\end{array}$} & \multirow{3}{*}{$\begin{array}{c}\begin{array}{c}\text { Blood Pressure } \\
\text { before Operation } \\
(\mathrm{mm} . \mathrm{Hg})\end{array} \\
-190,105-165100\end{array}$} & \multicolumn{3}{|c|}{$\begin{array}{c}\text { Blood Pressure at } \\
\text { Operation ( } \mathrm{mm} . \mathrm{Hg})\end{array}$} & \multirow{3}{*}{$\begin{array}{l}\text { Anaesthesia } \\
\underset{\text { Laudolissin }}{\mathrm{N}_{2} \mathrm{O}}\end{array}$} & \multirow{2}{*}{\multicolumn{2}{|c|}{$\begin{array}{c}\text { Amount } \\
\text { (mg.) and } \\
\text { No. of } \\
\text { Injections of } \\
\text { Pendiomid }\end{array}$}} & \multirow{3}{*}{$\begin{array}{c}\begin{array}{c}\text { Blood } \\
\text { During } \\
\text { Opera- } \\
\text { tions } \\
(\mathrm{ml} .)\end{array} \\
450\end{array}$} & \multirow{3}{*}{$\frac{\begin{array}{l}\text { Urinary } \\
\text { Output }\end{array}}{\text { Normal }}$} & \multirow{3}{*}{\begin{tabular}{|}
$\begin{array}{c}\text { Post- } \\
\text { operative } \\
\text { Course }\end{array}$ \\
$\begin{array}{c}\text { Uncom- } \\
\text { plicated }\end{array}$
\end{tabular}} & \multirow{3}{*}{$\begin{array}{c}\text { Remarks } \\
\begin{array}{l}\text { Short period of } \\
\text { hypotension } \\
\text { post-opera- } \\
\text { tively }\end{array}\end{array}$} \\
\hline & & & \multirow{3}{*}{$\begin{array}{c}\begin{array}{c}\text { Just } \\
\text { Before }\end{array} \\
220170 \\
20090\end{array}$} & \multirow{3}{*}{$\begin{array}{c}\begin{array}{c}\text { Lowest } \\
\text { During }\end{array} \\
11080 \\
9060\end{array}$} & \multirow{2}{*}{$\frac{\text { After }}{12090}$} & & & & & & & \\
\hline & & & & & & & 270 & 7 & & & & \\
\hline 2 & 200 & 200100 & & & 14085 & Pentothal, $\mathrm{N}_{2} \mathrm{O}$, & 400 & 7 & 800 & , & , & \\
\hline 3 & $16 q$ & $16080-130,65$ & 13090 & 9070 & 140100 & $\begin{array}{l}\text { Laudolissin } \\
\text { Narcodorm, }\end{array}$ & 475 & 9 & 500 & , & , & \\
\hline 4 & $21 q$ & 13090 & 13595 & 6040 & 11585 & $\begin{array}{l}\text { Narcodorm, } \\
\text { No. Flaxedil }\end{array}$ & 225 & 7 & 800 & , & , & \\
\hline 5 & $11 f$ & $205,160-170110$ & 220175 & 9585 & $160 \quad 135$ & $\begin{array}{c}\text { Pentothal, } \mathrm{N}_{2} \mathrm{O} \text {, } \\
\text { Laudolissin }\end{array}$ & 350 & 7 & 250 & , & , & \\
\hline 6 & $15 \sigma^{*}$ & 14090 & 190115 & $95 / 75$ & $130 / 90$ & $\begin{array}{l}\text { Narcodorm, } \\
\mathrm{N}_{2} \mathrm{O} \text {, } \\
\text { Laudolissin }\end{array}$ & 200 & 7 & 250 & ", &, & \\
\hline 7 & 10 & 11070 & 140.95 & 8560 & 11080 & $\begin{array}{l}\text { Laucodorm, } \\
\mathrm{N}_{2} \mathrm{O} \text {, Flaxedil }\end{array}$ & 250 & 9 & 300 & , & , & \\
\hline 8 & 50 & 15050 & & 10065 & $140 / 100$ & $\begin{array}{l}\mathrm{N}_{2} \mathrm{O} \text {. } \\
\text { Laudolissin }\end{array}$ & 80 & 4 & 1,000 & , & $\begin{array}{l}\text { Atelec- } \\
\text { tases }\end{array}$ & $\begin{array}{c}\text { Cardiac arrest } \\
\text { during opera- } \\
\text { tion. Coexis- } \\
\text { ting ventricu- } \\
\text { lar septal } \\
\text { defect }\end{array}$ \\
\hline 9 & 1012 & 90.40 & & 6545 & 95,70 & Cycloprop. & 40 & 5 & 175 & , & $\begin{array}{l}\text { Uncom- } \\
\text { plicated }\end{array}$ & \\
\hline 10 & $11^{+}+$ & 150,90 & 200130 & 100 & 160105 & $\begin{array}{l}\mathrm{N}_{2} \mathrm{O} \text {, cycloprop., } \\
\text { Flaxedil }\end{array}$ & 325 & 6 & 500 & , & , & \\
\hline 11 & 13 \& & 13090 & 12085 & 6550 & 12090 & $\begin{array}{l}\text { Narcodorm, } \\
\mathrm{N}_{2} \mathrm{O} \text {, Scoline, } \\
\text { Laudolissin }\end{array}$ & 135 & 5 & 600 & & & $\begin{array}{l}\text { Died one hour } \\
\text { after opera- } \\
\text { tion (see text) }\end{array}$ \\
\hline 12 & $17 q$ & $160 / 110-125 / 90$ & 16090 & $75 / 60$ & $120 / 90$ & $\begin{array}{l}\mathrm{Narcodorm}_{\text {, }} \\
\mathrm{N}_{2} \mathrm{O} \text {, Scoline, } \\
\text { Laudolissin }\end{array}$ & 175 & 6 & 500 & Norm 1 & $\begin{array}{l}\text { Uncom- } \\
\text { plicated }\end{array}$ & \\
\hline 13 & $11 \sigma^{*}$ & $15090-14090$ & 140100 & 9080 & $130: 100$ & $\begin{array}{l}\text { Narcodorm, } \\
\mathrm{N}_{2} \mathrm{O} \text {, Scoline, } \\
\text { Laudolissin }\end{array}$ & 175 & 5 & 400 & , & , & \\
\hline 14 & 45 & $12580-11060$ & 15095 & 8065 & 12090 & $\mathrm{~N}_{2} \mathrm{O}$, cycloprop. & 125 & 5 & 200 & , & , & $\begin{array}{l}\text { Only an explor- } \\
\text { atory opera- } \\
\text { tion }\end{array}$ \\
\hline 15 & $6 \hat{0}$ & $240140-220 / 130$ & 270180 & 10070 & 280200 & $\mathrm{~N}_{2} \mathrm{O}$, cycloprop. & 80 & 4 & 350 & $\underset{\text { text }}{\text { See }}$ & $\underset{\text { text }}{\text { See }}$ & $\begin{array}{l}\text { Re-operated } \\
\text { on 13th day } \\
\text { Died shortly } \\
\text { after }\end{array}$ \\
\hline 16 & $390^{*}$ & $190 / 120$ & 190100 & 8570 & 12585 & $\begin{array}{l}\text { Narcodorm, } \\
\mathrm{N}_{2} \mathrm{O} \text {, Flaxedil }\end{array}$ & 700 & 12 & 550 & Normal & $\begin{array}{l}\text { Uncom- } \\
\text { plicated }\end{array}$ & \\
\hline 17 & $13 q$ & $150 / 80-14070$ & 13090 & 7050 & 14090 & $\begin{array}{l}\text { Narcodorm, } \\
\mathrm{N}_{2} \mathrm{O} \text {, Flaxedil }\end{array}$ & 200 & 5 & 400 & , & , & \\
\hline 18 & 36 ㅇ & 22080 & 23590 & 9040 & 170105 & $\begin{array}{l}\text { Narcodorm, } \\
\mathrm{N}_{2} \mathrm{O} \text {, Scoline, } \\
\text { Laudolissin }\end{array}$ & 275 & 7 & 500 & , & , & \\
\hline
\end{tabular}

Case 15, a 5-year-old boy, had a very high blood pressure, $230 / 130 \mathrm{~mm}$. $\mathrm{Hg}$, before operation. Pendiomid worked well, decreasing the pressure to $100 / 70$ to $120 / 80 \mathrm{~mm}$. $\mathrm{Hg}$. Thoracotomy revealed that, in addition to the coarctation, the part of the descending aorta beyond the origin of the left subclavian artery was hypoplastic in its entire course in the chest, being only about half the diameter of the aorta proximal to the stenosis. A piece was resected and proved to contain a coarctation. After the operation was completed the blood pressure again increased, being for a time about $300 / 240 \mathrm{~mm}$. $\mathrm{Hg}$, until it settled at about $240 / 120$ $\mathrm{mm} . \mathrm{Hg}$. Post-operatively there were fluctuations in the daily urinary output, which fell to $50 \mathrm{ml}$, and then increased to $350 \mathrm{ml}$., and later fell to $100 \mathrm{ml}$. in the course of a few days and then down to $25 \mathrm{ml}$. The blood urea nitrogen increased to $340 \mathrm{mg}$. \%. On the thirteenth day re-operation was performed (without hypotension) because of signs of thrombosis at the site of resection. This time about $7 \mathrm{~cm}$. of the aorta was removed. The specimen proved to be packed with thrombi. A graft was inserted. The patient died on the following day. Necropsy showed that the entire descending aorta was hypoplastic, but the size of the renal arteries was normal. In the left kidney there was a fresh infarct, 3 by $3 \mathrm{~cm}$. The heart was hypertrophic. There was thus ample explanation of the renal insufficiency. The induced hypotension was unlikely to have contributed significantly to the death.

Case 14 only had an exploratory operation. It revealed an extensive stenosis of the aorta with 
fairly good passage, so resection was not deemed advisable.

Owing to a misunderstanding Case 4 received a large amount of blood $(1,000 \mathrm{ml}$.) post-operatively, but this did not influence the post-operative course.

It is difficult to estimate reliably whether the total amount of blood administered in this series was materially smaller than in the previous group. The general impression, however, is that haemorrhage was considerably less and that the operations were made technically easier because of controlled hypotension. This applies particularly to dissection and ligation of the intercostal arteries.

In 14 cases the post-operative course was uneventful, and the renal function seems to have been unaffected in all (16).

During the immediate post-operative period in most of the patients blood pressure rose until it approximated the pre-operative level. The pressure then declined until normal levels were reached within a week or two. This initial increase, which occurs also in patients who have not had controlled hypotension, is somewhat delayed after administration of "pendiomid," as the effect of the drug usually persists for some hours after the operation is completed ; this is apparent from the persistent dilatation of the pupils. Frequently the patients are pale, but they are usually warm and feel well.

\section{CONClUSion AND SUMmary}

From our use of controlled hypotension during operation for coarctation of the aorta we believe that the procedure helps during operation. It makes the operative technique considerably easier, facilitating haemostasis and diminishing bleeding. In a series of 18 patients, 17 resections and one exploratory intervention were carried out with two deaths.* Stress must be laid on the fact that patients with controlled hypotension are extremely sensitive to postural changes, and this may have been a contributory cause of one of the deaths in our series. In this study the controlled hypotension was induced by "pendiomid" (Ciba), a relatively short-acting ganglion-blocking drug.

So far, the value of the procedure is a matter of conjecture. A more reliable comparison with our previous results can be made only when the present series has increased in number and includes more adults. At the moment we consider controlled hypotension to be a well worth-while advance in the surgical technique for the relief of coarctation of the aorta.

\footnotetext{
* Since this paper was written six further similar cases have been operated on with the same good results.

REFERENCES

Davison, M. H. A. (1950). Lancet, 1, 252.

Enderby, G. E. H. (1950). Ibid., 1, 1145.

Griffith, H. W. (1954). Personal communication.

Lucas, B. (1954). Personal communication.

Lundskog, O. (1954). Personal communication.
} 